\title{
Piecing together the problems in diagnosing low- level chromosomal mosaicism
}

\author{
Caroline Robberecht, Jean-Pierre Fryns and Joris Robert Vermeesch*
}

\begin{abstract}
Low-level somatic chromosomal mosaicism, which usually arises from post-zygotic errors, is a known cause of several well defined genetic syndromes and has been implicated in various multifactorial diseases. It is, however, not easy to diagnose, as various physical and technical factors complicate its identification.
\end{abstract}

\section{Developmental origins of mosaicism}

Chromosomal mosaicism is defined as the presence of two or more karyotypically different cell lines in the same individual. Somatic mosaicism mostly results from postzygotic errors in recombination or replication. Whole chromosomal aneuploidies (in which there are more than or fewer than two copies of one or more chromosomes) can arise by non-disjunction or anaphase lagging. Imbalances of chromosomal segments can originate from unrepaired breakages.

Chromosome instability is common in human cleavagestage embryos that have been fertilized in vitro. This has become more apparent through the application of new techniques for the analysis of the chromosome content of single blastomeres. Recent array comparative genomic hybridization (array CGH) analysis [1] of normally developing, good quality preimplantation embryos confirmed the presence of a high percentage of chromosomal abnormalities at cleavage stage. In addition, this analysis [1] showed that all abnormal embryos were mosaic for the aberrations found and that not only could whole chromosome aneuploidies be detected, but also a significant number of segmental aberrations. Most of these embryos are selected against during the first days and weeks of gestation. As a consequence mosaicism is observed in just $5 \%$ of aneuploid spontaneous miscarriages between 6 and 20 weeks [2] and in only 1 to $2 \%$

*Correspondence: Joris.Vermeesch@uz.kuleuven.ac.be

Center for Human Genetics, University Hospital Gasthuisberg, Catholic University of Leuven, Herestraat 49, 3000 Leuven, Belgium of viable pregnancies screened by chorionic villus sampling $[3,4]$.

\section{The role of somatic mosaicism in disease}

Somatic mosaicism contributes to variations in phenotypic expression and disease and has important clinical consequences. Constitutional chromosomal mosaicism has been implicated as a cause of several well described genetic syndromes. The best characterized mosaic syndrome is Pallister-Killian syndrome. This syndrome is a clinically recognizable, multiple malformation syndrome with distinct facial features and is often associated with a diaphragmatic hernia that can lead to neonatal death. It is caused by the presence of an isochromosome $12 p$, which is an abnormal extra chromosome consisting of two copies of the short arm of chromosome 12 fused at the centromere, resulting in tetrasomy $12 p[5,6]$. This isochromosome is mainly observed in fibroblasts but is found in only very low numbers in circulating blood lymphocytes [7]. Other such small supernumerary marker chromosomes, defined as structurally abnormal chromosomes that cannot be identified or characterized unambiguously by conventional banding techniques alone, are also present in only a subset of cells in the majority of affected individuals [8]. In addition, almost all known chromosomal anomalies have been detected in a mosaic state in occasional patients [9].

The presence of such low-level mosaic chromosome abnormalities has also been linked to several multifactorial diseases. It has, for example, been implicated as a genetic risk factor in children with syndromic autism $[10,11]$. Moreover, mosaic gains or losses of whole chromosomes have recently been described in the human brain $[12,13]$ and may contribute to certain brain pathologies, such as schizophrenia and Alzheimer's disease $[14,15]$.

Mosaicisms are also important in acquired disorders. Cancer is one of the most prominent forms of somatic mosaicism, and chromosomal copy-number aberrations are a frequent finding in solid tumors [16]. The organism affected with such an alteration is a somatic mosaic, in which the cancerous tissue often has a different genetic constitution from the rest of the body. 


\section{Detection of somatic mosaicism}

The true incidence of chromosomal mosaicism causing significant phenotypic effects is unknown but is probably greater than 1 in 10,000. It seems likely, however, that chromosomal mosaicism is underdiagnosed, for two main reasons [17]. First, unless some phenotypic clues (such as discrepancies in body symmetry, pigmentation or facial appearance) indicate the presence of mosaic somatic changes, their occurrence often goes undetected. A study on phenotypically 'normal' individuals using multiplex PCR of seven simple, short tandem repeats showed that trisomies and translocations at each locus examined occurred with an incidence of 1 in 2,000 samples $[18,19]$. Identification of somatic mosaicism is also clearly hampered by the process of tissue sampling. Aberrations that formed at particular stages of development might be present only in a specific tissue (such as brain tissue or fibroblasts) and could easily be missed in a blood karyotype.

Low-level mosaicisms have long been recognized and were first identified by karyotyping. A common routine test analyzes 20 metaphases from stimulated T-cell cultures, and this enables the detection of an abnormality in $21 \%$ or more of the cells with $99 \%$ confidence [20]. If the percentage of affected cells is smaller, they can be missed, interpreted as normal variation in the population or dismissed as a culture artifact. Several studies have shown that there is preferential growth of the normal cells in stimulated blood cultures, leading to an underestimation of the percentage of abnormal cells or to the aberration going completely undetected [21-23].

The introduction of fluorescent in situ hybridization (FISH) enabled the analysis of large numbers of cells at a higher resolution (about 80 to 200 kilobases) [24] and lower-level mosaicisms could thereby be detected. Unfortunately, FISH looks at only a single specific locus and mosaicism of this locus must therefore be suspected beforehand. With the use of array CGH, genome-wide analysis of mosaic imbalances has become a routine possibility. Several cases of mosaicism have been detected by array CGH [21,22]. Low-level mosaicisms have been described in constitutional disorders, with abnormal cells making up 7 to $30 \%$ of cells [22,23,25-27], as well as in cancers [28-30]. The first reports on array CGH showed the ability to detect low-level mosaics, and sporadic reports show that mosaicism as low as $5 \%$ can be detected by bacterial artificial chromosome (BAC)-based array CGH [23]. Studies investigating the lower detection limits show that BAC and oligonucleotide arrays enable the detection of 10 to $20 \%$ of mosaicisms in a systematic way $[21,31]$. However, these percentages are reached only if dye swap experiments are performed and no threshold filters are applied, as the deviance from zero might be subtle [31].

\section{The future: improvements and applications}

Further increases in sensitivity are warranted for a better diagnosis. First, some smaller copy-number variants can be present in a mosaic form. Second, some aneuploidies can be present in a small minority of the blood cells, the tissue on which tests are most often performed, but can be present in higher numbers in other tissues. For example, the identification of a small percentage of isochromosome 12p in blood cells can enable the diagnosis of Pallister-Killian syndrome.

Finally, methods used in the detection of low grade mosaics may open up new areas of diagnosis in other fields. For example, DNA in the plasma of cancer patients contains circulating DNA derived from the tumor, which might be distinguished from normal DNA by such methods. Equally, it might become possible to detect fetal aneuploidies by screening the plasma of pregnant women. The ability to detect this DNA by genome-wide screening methods would open new diagnostic possibilities.

\section{Abbreviations \\ Array CGH, array comparative genomic hybridization; FISH, fluorescent in situ hybridization.}

\section{Authors' contributions}

CR and JRV wrote the manuscript. All authors read the manuscript critically.

Competing interests

The authors declare that they have no competing interests.

\section{Acknowledgements}

This work has been made possible by an IWT (SBO 60848) and FWO grant G.0320.07.

\section{Published: 29 July 2010}

\section{References}

1. Vanneste E, Voet T, Le Caignec C, Ampe M, Konings P, Melotte C, Debrock S, Amyere M, Vikkula M, Schuit F, Fryns JP, Verbeke G, D'Hooghe T, Moreau Y, Vermeesch JR: Chromosome instability is common in human cleavagestage embryos. Nat Med 2009, 15:577-583.

2. Hassold T: Mosaic trisomies in human spontaneous-abortions. Hum Genet 1982, 61:31-35.

3. Ledbetter DH, Zachary JM, Simpson JL, Golbus MS, Pergament E, Jackson L, Mahoney MJ, Desnick RJ, Schulman J, Copeland KL, et al: Cytogenetic results from the United-States Collaborative Study on CVS. Prenat Diagn 1992, 12:317-345.

4. Wang BB, Rubin $\mathrm{CH}$, Williams J III: Mosaicism in chorionic villus sampling: an analysis of incidence and chromosomes involved in 2612 consecutive cases. Prenat Diagn 1993, 13:179-190.

5. Hunter AG, Clifford B, Cox DM: The characteristic physiognomy and tissue specific karyotype distribution in the Pallister-Killian syndrome. Clin Genet 1985, 28:47-53.

6. Peltomaki P, Knuutila S, Ritvanen A, Kaitila I, Delachapelle A: Pallister-Killian syndrome - cytogenetic and molecular studies. Clin Genet 1987, 31:399-405.

7. Reynolds JF, Daniel A, Kelly TE, Gollin SM, Stephan MJ, Carey J, Adkins WN, Webb MJ, Char F, Jimenez JF, et al: Isochromosome 12P mosaicism (Pallister mosaic aneuploidy or Pallister-Killian syndrome) - report of 11 cases. Am J Med Genet 1987, 27:257-274

8. Liehr T, Mrasek K, Weise A, Dufke A, Rodriguez L, Martinez GN, Sanchis A, Vermeesch JR, Ramel C, Polityko A, Haas OA, Anderson J, Claussen U, Von Eggeling F, Starke H: Small supernumerary marker chromosomes - progress towards a genotype-phenotype correlation. Cytogenet Genome Res 2006, 112:23-34. 
9. Schinzel A: Catalogue of Unbalanced Chromosome Aberrations in Man. Berlin, New York: De Gruyter, Walter, Inc.; 2001.

10. Iourov IY, Yurov YB, Vorsanova SG: Mosaic X chromosome aneuploidy can help to explain the male-to-female ratio in autism. Med Hypotheses 2008, 70:456.

11. Yurov YB, Vorsanova SG, lourov IY, Demidova IA, Beresheva AK, KravetzVS, Monakhov WV, Kolotii AD, Voinova-Ulas VY, Gorbachevskaya NL: Unexplained autism is frequently associated with low-level mosaic aneuploidy. J Med Genet 2007, 44:521-525.

12. Yurov YB, lourov IY, Vorsanova SG, Liehr T, Kolotii AD, Kutsev SI, Pellestor F, Beresheva AK, Demidova IA, Kravets VS, Monakhov VV, Soloviev IV: Aneuploidy and confined chromosomal mosaicism in the developing human brain. PLOS ONE 2007, 2:e558.

13. Yurov YB, lourov IY, Vorsanova SG, Demidova IA, Kravetz VS, Beresheva AK, Kolotii AD, Monakchov VV, Uranova NA, Vostrikov VM, Soloviev IV, Liehr T: The schizophrenia brain exhibits low-level aneuploidy involving chromosome 1. Schizophr Res 2008, 98:139-147.

14. lourov IY, Liehr T, Vorsanova SG, Kolotii AD, Yurov YB: Visualization of interphase chromosomes in postmitotic cells of the human brain by multicolour banding (MCB). Chromosome Res 2006, 14:223-229.

15. Kingsbury MA, Yung YC, Peterson SE, Westra JW, Chun J: Aneuploidy in the normal and diseased brain. Cell Mol Life Sci 2006, 63:2626-2641.

16. Albertson DG, Collins C, McCormick F, Gray JW: Chromosome aberrations in solid tumors. Nat Genet 2003, 34:369-376.

17. Woods CG, Bankier A, Curry J, Sheffield LJ, Slaney SF, Smith K, Voullaire L, Wellesley D: Asymmetry and skin pigmentary anomalies in chromosome mosaicism. J Med Genet 1994, 31:694-701.

18. Sparkes R, Kimpton C, Watson S, Oldroyd N, Clayton T, Barnett L, Arnold J, Thompson C, Hale R, Chapman J, Urquhart A, Gill P: The validation of a 7-locus multiplex STR test for use in forensic casework. (I). Mixtures, ageing, degradation and species studies. Int J Legal Med 1996, 109:186-194.

19. Youssoufian H, Pyeritz RE: Mechanisms and consequences of somatic mosaicism in humans. Nat Rev Genet 2002, 3:748-758

20. Hook EB: Exclusion of chromosomal mosaicism: tables of $90 \%, 95 \%$ and $99 \%$ confidence limits and comments on use. Am J Hum Genet 1977. 29:94-97.

21. Ballif BC, Rorem EA, Sundin K, Lincicum M, Gaskin S, Coppinger J, Kashork CD, Shaffer LG, Bejjani BA: Detection of low-level mosaicism by array CGH in routine diagnostic specimens. Am J Med Genet A 2006, 140:2757-2767.

22. Cheung SW, Shaw CA, Scott DA, Patel A, Sahoo T, Bacino CA, Pursley A, Li J, Erickson R, Gropman AL, Miller DT, Seashore MR, Summers AM, Stankiewicz P, Chinault AC, Lupski JR, Beaudet AL, Sutton VR: Microarray-based CGH detects chromosomal mosaicism not revealed by conventional cytogenetics. Am J Med Genet A 2007, 143A:1679-1686.
23. Menten B, Maas N, Thienpont B, Buysse K, Vandesompele J, Melotte C, de Ravel T, Van Vooren S, Balikova I, Backx L, Janssens S, De Paepe A, De Moor B, Moreau Y, Marynen P, Fryns JP, Mortier G, Devriendt K, Speleman F, Vermeesch $J R$ : Emerging patterns of cryptic chromosomal imbalance in patients with idiopathic mental retardation and multiple congenital anomalies: a new series of 140 patients and review of published reports. J Med Genet 2006, 43:625-633.

24. Shaffer LG, Ledbetter DH, Lupski JR: Molecular cytogenetics of contiguous gene syndromes: mechanisms and consequences of gene dosage imbalances. In The Metabolic and Molecular Basis of Inherited Disease. Edited by Scriver C, Beaudet A, Sly W, Valle D, Childs B, Kinzler K, et al. New York: McGraw Hill; 2001:1291-1324.

25. Powis Z, Kang SH, Cooper ML, Patel A, Peiffer DA, Hawkins A, Heidenreich R, Gunderson KL, Cheung SW, Erickson RP: Mosaic tetrasomy 12p with triplication of $12 p$ detected by array-based comparative genomic hybridization of peripheral blood DNA. Am J Med Genet A 2007, 143A:2910-2915

26. Schaeffer AJ, Chung J, Heretis K, Wong A, Ledbetter DH, Martin C: Comparative genomic hybridization-array analysis enhances the detection of aneuploidies and submicroscopic imbalances in spontaneous miscarriages. Am J Hum Genet 2004, 74:1168-1174.

27. Shinawi M, Shao L, Jeng $\perp$, Shaw CA, Patel A, Bacino C, Sutton VR, Belmont J, Cheung SW: Low-level mosaicism of trisomy 14: phenotypic and molecular characterization. Am J Med Genet A 2008, 146A:1395-1405.

28. Albertson DG, Pinkel D: Genomic microarrays in human genetic disease and cancer. Hum Mol Genet 2003, 12:R145-R152.

29. Pinkel D, Albertson DG: Array comparative genomic hybridization and its applications in cancer. Nat Genet 2005, 37:S11-S17.

30. Wozniak A, Sciot R, Guillou L, Pauwels P, Wasag B, Stul M, Vermeesch JR, Vandenberghe P, Limon J, Debiec-Rychter M: Array CGH analysis in primary gastrointestinal stromal tumors: Cytogenetic profile correlates with Anatomic site and tumor aggressiveness, irrespective of mutational status. Genes Chromosomes Cancer 2007, 46:261-276.

31. Scott SA, Cohen N, Brandt T, Toruner G, Desnick RJ, Edelmann L: Detection of low-level mosaicism and placental mosaicism by oligonucleotide array comparative genomic hybridization. Genet Med 2010, 12:85-92.

doi:10.1186/gm168

Cite this article as: Robberecht $C$, et al.: Piecing together the problems in diagnosing low-level chromosomal mosaicism. Genome Medicine 2010, 2:47. 